\title{
A primeira greve nacional da classe trabalhadora brasileira: 5 de julho de 1962
}

\author{
Demian Bezerra de Melo*
}

Resumo: No início de julho de 1962, uma greve geral paralisou grande parte do país. Seu propósito foi eminentemente político: intervir na luta travada entre o presidente João Goulart e o Congresso Nacional, para favorecer o primeiro na definição da composição do Conselho de Ministros Parlamentarista. A greve paralisou toda a região que compreendia o antigo estado da Guanabara (atual cidade do Rio de Janeiro) e o estado do Rio de Janeiro, toda a Baixada Santista, o Porto de Paranaguá (PR), o Rio Grande do Sul e grande parte das capitais nordestinas. Por sua dimensão, o movimento chamou atenção até do serviço de inteligência dos EUA. O propósito deste artigo é discutir o desenvolvimento e o significado da que foi a primeira greve nacional da classe trabalhadora brasileira.

Palavras-chave: movimento sindical; greve geral; governo João Goulart.

Abstract: In early July 1962 a general strike paralyzed much of the country. Its purpose was essentially political: to intervene in the struggle between President João Goulart and the National Congress, to favor the first in the definition of the composition of the Parliamentary Council of Ministers. The strike paralyzed the entire region that included the old state of Guanabara (today the city of Rio de Janeiro) and the state of Rio de Janeiro, all the Baixada Santista, the Port of Paranaguá (PR), Rio Grande do Sul and most northeastern capitals. Because if its size, the movement drew attention to the U.S. intelligence service. The purpose of this paper is to discuss the development and significance of that which was the first national strike of the Brazilian working class.

Keywords: trade Union movement; general strike; João Goulart government.

* Doutor em História pela Universidade Federal Fluminense (UFF). Professor Adjunto de História Contemporânea do curso de Políticas Públicas da UFF. Este artigo se baseia em alguns resultados de nossa tese de doutorado, Crise orgânica e ação política da classe trabalhadora brasileira: a primeira greve geral nacional (5 de julho de 1962), defendida no Programa de Pós-Graduação em História da Universidade Federal Fluminense, em 2013, com bolsa da Coordenação de Aperfeiçoamento de Pessoal de Nível Superior (CAPES). Agradeço as preciosas considerações feitas pelo parecerista anônimo deste manuscrito, cabendo ressaltar minha inteira responsabilidade sobre o texto. 
Já passava do meio do dia 4 de julho de 1962, quando o Comando Geral de Greve se reuniu na sede da Confederação Nacional dos Trabalhadores na Indústria (CNTI), localizada naquela época nas imediações da Rua dos Andradas com a Marechal Floriano, no centro do Rio de Janeiro. Estavam ali Dante Pelacani, que dirigiu os trabalhos ao lado de Hércules Correia, o qual propôs a deflagração de uma greve política nacional de 24 horas, e o presidente da UNE, Aldo Arantes, que imediatamente apoiou a proposta. Pelacani era um ex-militante do Partido Comunista Brasileiro (PCB) que havia se convertido ao Partido Trabalhista Brasileiro (PTB) em 1958, tornando-se uma das mais expressivas lideranças do trabalhismo na área sindical. O presidente da UNE era um católico de esquerda, enquanto Correia um histórico comunista. Todos eram membros das principais forças políticas no movimento operário e popular que apoiavam a agenda reformista apresentada pelo presidente João Goulart durante seu breve governo (1961-1964).

Representantes das mais importantes entidades de cúpula da estrutura sindical oficial, como a Confederação Nacional dos Trabalhadores em Empresas de Crédito (CONTEC) - cuja base era formada basicamente pelo sindicalismo bancário - além de representantes de enlaces sindicais extralegais, como a Comissão Permanente de Organizações Sindicais da Guanabara, ou o Pacto de Unidade e Ação (PUA) - que congregava marítimos, portuários e ferroviários -, davam a dimensão da reunião ocorrida naquela tarde de quarta-feira. Do plenário, intervieram, entre outros, o líder dos estivadores de Santos e dirigente do PUA, o sergipano Osvaldo Pacheco, o ferroviário Rafael Martinelli, o bancário Luiz Viegas da Mota Lima, o operário marceneiro Roberto Morena, todos esses comunistas, além do ferroviário petebista pernambucano Cláudio Braga. Após a decisão tomada naquela tarde, senhas foram distribuídas a muitos sindicatos do país e à zero hora do dia 5 a greve pipocou em várias regiões. Foi uma greve política, ${ }^{1}$ a primeira greve geral nacional da classe trabalhadora brasileira cujo objetivo era intervir diretamente no conflito político entre o presidente João Goulart e o Congresso Nacional, barganhando uma pauta no interesse econômico da classe trabalhadora. ${ }^{2}$

Além do ineditismo, seu significado histórico esteve ligado às lutas decisivas travadas sob o governo de João Goulart, no primeiro ano após sua posse, quando este se batia pela recuperação dos poderes que lhe haviam sido tolhidos pela emenda constitucional parlamentarista. Nas páginas seguintes, veremos em que condições do processo político brasileiro eclodiu tal movimento, sua dimensão nacional, importância política e fracassos.

1 A noção de greve política remete diretamente ao objetivo político de um determinado movimento paredista de trabalhadores cujo alvo é o Estado, particularmente o governo e/ou Parlamento. Até por seu aspecto abrangente, as greves gerais assumem com frequência uma conotação política. A propósito, a definição de uma greve como "política" é parte da própria luta política, como assinala Bourdieu. BOURDIEU, Pierre. "A greve e a ação política". In: Questões de sociologia. Rio de Janeiro: Marco Zero, 1983, p. 195-204. No seu verbete ao Dicionário de Política, Marino Regini escreve que as greves "têm sido e é um recurso importante também no conflito político. No fim do século XIX e no início do século XX, as massas operárias procuravam por meio da greve conseguir não somente um melhoramento das próprias condições de salário e de trabalho, mas também a extensão do sufrágio. Ainda hoje, muitos movimentos operários se servem da greve (especialmente a greve geral) para impor ao Estado a adoção de políticas econômicas e sociais ou de leis a eles favoráveis." REGINI, M. Greve. In: BOBBIO, Norberto; MATTEUCCI, Nicola; PASQUINO, Gianfranco (org.). Dicionário de Política. Brasília: Ed. UNB, 1998, p. 560-562.

2 MELO, Demian Bezerra de. Crise orgânica e ação política da classe trabalhadora brasileira: a primeira greve geral nacional (5 de julho de 1962). (Tese de doutorado em História, Universidade Federal Fluminense, 2013). 


\section{O processo político brasileiro}

O país vivia sob estado de expectativa desde setembro de 1961, quando subiu à Presidência da República o herdeiro político de Vargas, João Goulart, o Jango, como ficou conhecido. A renúncia surpreendente do presidente Jânio Quadros em 25 de agosto, o manifesto dos ministros militares vetando a posse do seu vice, o levantamento da região Sul a partir da iniciativa do governador gaúcho Leonel Brizola, um acordo costurado pelo Congresso que introduziu o sistema de governo parlamentarista, etc., são episódios por demais lembrados quando o assunto é o governo Jango. ${ }^{3}$ Tendo ficado o país à beira da guerra civil, a "solução parlamentarista" parecia a forma mais razoável de contornar a crise. Contudo, tal acordo escondia o cerne de uma nova crise.

Comum aos governos durante a República de 1946, a estabilidade política era garantida com o apoio firme nos quartéis e pelos mecanismos de contenção das contradições do capitalismo brasileiro a partir da estrutura sindical, além, é claro, dos arranjos político-partidários. ${ }^{4} \mathrm{Na}$ área militar, Jango pôde contar com o apoio das alas legalista e nacionalista das Forças Armadas, tendo a resistência ao golpe em 1961 sedimentado o apoio de parcelas significativas da oficialidade ao seu governo. Como parte importante da base de apoio ao seu governo, Goulart em toda sua carreira cultivou relações de proximidade com o ativismo sindical, e uma vez no governo não o desprezaria. Basta dizer que logo no início do seu governo patrocinou uma mudança na composição da diretoria da CNTI, com a ascensão de elementos mais à esquerda do seu partido, o PTB, aliados dos comunistas. Desse modo, a esquerda sindical assumiu posição relevante na mais importante confederação de trabalhadores da estrutura sindical oficial. Desde sua fundação (1947) até fins de 1961, a CNTI foi uma dócil promotora da subordinação da vida sindical ao Estado; com tal mudança ideológica na direção política da entidade, passou a organizar as lutas trabalhistas.

Voltando ao cenário político que possibilitou a greve geral de julho de 1962, já em junho daquele ano a crise voltava à superfície do sistema político, reabrindo as fissuras do frágil acordo que engendrou o parlamentarismo no ano anterior. Naquela breve experiência, o primeiro gabinete foi de "união nacional", isto é, composto pelos principais partidos do espectro político - inclusive a antigetulista União Democrática Nacional (UDN) -, e tendo à sua frente Tancredo Neves, do centrista Partido Social Democrático (PSD) mineiro. Tinha-se, desse modo, um governo baseado num grande acordo entre todas as forças políticas decisivas, acordo esse que não estava naturalmente baseado em qualquer aspecto programático - o que seria impossível. Desse modo, a tal "união nacional" não poderia durar muito tempo. Além disso, a instituição de um sistema de gabinete em um regime político baseado na Carta Presidencialista de 1946 - saída conciliatória para evitar que a crise provocada pela renúncia de Jânio Quadros desembocasse numa guerra civil -, não poderia gerar outros frutos senão uma nova crise.

Logo em sua primeira reforma ministerial, o castelo de cartas ruiu. De acordo com a híbrida fórmula institucional vigente, os postulantes às eleições de 7 de outubro daquele ano deveriam se desincompatibilizar alguns meses antes do

3 BANDEIRA, Luiz Alberto Moniz. O governo João Goulart e as lutas sociais no Brasil, 1961-1964. $7^{\mathrm{a}}$ edição, revista e ampliada. Rio de Janeiro: Revan; Brasília: Ed. da UnB, 2001.

4 Cf. ROUQUIÉ, Alain (org.). Os partidos militares no Brasil. Rio de Janeiro: Record, s.d. MARINI, Ruy Mauro. A dialética do desenvolvimento capitalista no Brasil. In: Subdesenvolvimento e revolução. Florianópolis: Insular, 2012, p. 73-160. DEMIER, Felipe. O longo bonapartismo (1930-1964). Rio de Janeiro: Mauad, 2013. 
pleito. Esse era o caso de muitos ministros, a começar pelo próprio Tancredo, que havia perdido as eleições para o governo de Minas Gerais em outubro de $1960^{5}$ e pretendia candidatar-se à Câmara Federal. O atributo de indicar um novo presidente para o Conselho de Ministros era do chefe de Estado, João Goulart, que deveria apresentar um nome para aprovação da Câmara. Ele precisava escolher alguém que pudesse ser aprovado pela maioria conservadora da Câmara Federal cujas maiores bancadas eram do PSD e da UDN; um nome que, ao mesmo tempo, fosse de sua confiança, isto é, afinado com seus confessados propósitos de liquidar o parlamentarismo.

O nome escolhido foi o do titular da pasta do Exterior, o empresário e trabalhista mineiro San Tiago Dantas, que era respeitado entre as esquerdas por sua postura em defesa da continuidade da chamada "Política Externa Independente" (iniciada por seu antecessor, o udenista Afonso Arinos de Melo Franco, sob a gestão Quadros), que se refletiu na defesa do princípio da autodeterminação de Cuba, motivo pelo qual era mal visto entre os círculos de direita. Antes de sua indicação por Jango, San Tiago havia recentemente passado por um teste no Congresso, quando, no fim de maio, uma moção de censura à sua política externa foi apresentada pelo deputado Eurípedes Cardoso de Meneses (UDN-GB), sendo rejeitada por 131 votos contra $44 .^{6}$

\section{A montagem do "dispositivo grevista"}

Ainda no início de junho, lideranças da esquerda sindical7 haviam declarado publicamente que estaria sendo preparada uma greve geral para apoiar a indicação de San Tiago Dantas, pois, acreditavam, este seria capaz de constituir um "gabinete nacionalista e democrático" que tivesse como programa a realização das reformas de base. Essa esquerda sindical começou a aprofundar suas articulações com vistas a construir um dispositivo grevista que funcionasse em apoio ao movimento nacionalista e em oposição a uma nova tentativa de golpe, denunciada pela oficialidade nacionalista. Esse é, aliás, um componente fundamental da relação de forças no contexto do início do governo Goulart: a divisão, na oficialidade militar, entre golpistas e legalistas. Desse modo, enquanto a direita fardada denunciava a "infiltração comunista" nas próprias Forças Armadas, o general nacionalista Osvino Ferreira Alves alertava para a existência de uma conspiração de extrema-direita com vistas à implantação de uma ditadura militar no país, provocando alvoroço entre as esquerdas. ${ }^{8}$

Em 4 de junho, San Tiago Dantas foi a uma solenidade no Sindicato dos Metalúrgicos da Guanabara onde proferiu uma conferência sobre a política externa. Conforme noticiou a imprensa sindical carioca, a massa operária que lotou as dependências da entidade aplaudiu entusiasticamente o chanceler, que também

5 O eleito foi Magalhães Pinto, da UDN.

6 Jornal do Brasil, Rio de Janeiro, 30 maio 1962. Desse modo, ao contrário da leitura da cientista política Argelina Figueiredo, a candidatura de Dantas não era uma manobra irresponsável de Goulart, mas seguiu uma estratégia consequente de liquidação do Parlamentarismo. Cf. FIGUEIREDO, Argelina C. Democracia ou Reformas? São Paulo: Paz e Terra, 1993.

7 Sobre a importância da aliança político-sindical entre comunistas e trabalhistas naquele período histórico, cf. SANTANA, Marco Aurélio. "Bravos companheiros: a aliança comunista-trabalhista no sindicalismo brasileiro (1945-1964)." In: FERREIRA, Jorge \& REIS, Daniel Aarão (orgs.). As esquerdas no Brasil. Nacionalismo e reformismo radical (1945-1964). Rio de Janeiro: Civilização Brasileira, 2007, p. $237-277$.

8 "General Peri: Bicho-papão do anticomunismo ameaça a Constituição" e "Gen. Osvino: trama golpista para implantar ditadura no país." Novos Rumos, Rio de Janeiro, 1 a 7 jun. 1962, p. 3 e 8. 
pôde ouvir do presidente em exercício da CNTI, Dante Pelacani, um manifesto no qual era exigida a formação de um Conselho de Ministros "democrático e nacionalista", capaz de realizar as tais "reformas de base". No mesmo documento, se denunciou a existência de rumores sobre um golpe direitista, contra o qual é anunciada a realização de uma greve geral para pressionar as instituições a repelirem tal ameaça. ${ }^{9}$

Alguns dias depois, em Recife, principal centro político nordestino, o semanário comunista A Hora estampava a manchete "Greve geral no país contra golpe". Na reportagem, são narradas reuniões e assembleias sindicais para a organização do dispositivo grevista nordestino, como aquela ocorrida no Sindicato dos Tecelões de Pernambuco, onde o próprio Dante Pelacani compareceu. ${ }^{10}$ Do mesmo modo, foram realizadas articulações regionais para a criação de um dispositivo de greve nacional. Via de regra, essas articulações regionais baseavamse em enlaces intersindicais de âmbito local, como os Conselhos Sindicais de Porto Alegre e Niterói, o Conselho Sindical dos Trabalhadores (Consintra) de Pernambuco, as Comissões Permanentes de Organizações Sindicais (CPOS) da Bahia e da Guanabara, a União Sindical do Ceará, o Fórum Sindical de Debates de Santos, entre outros.

A ideia original era que a greve ocorresse para forçar o Parlamento a aceitar o nome do ex-chanceler, mas não houve nenhum sinal dela no momento em que o nome de San Tiago Dantas foi submetido à apreciação da Câmara, em 28 de junho, sendo recusado por 172 votos contra 111. Apenas em Salvador, o que seria uma simples manifestação da esquerda nacionalista em desagravo a Goulart, Dantas e "contra a carestia", acabou em mais um ato de truculência desmedida do governador udenista Juracy Magalhães. Em reação, foi decretada greve geral de 24 horas em toda a cidade de Salvador, paralisando principalmente marítimos, portuários, bancários e operários do petróleo. ${ }^{11}$ Enquanto isso, atônitos, e sem acreditar que a Câmara tivesse tido a ousadia de negar a indicação feita pelo presidente da República, o Comando Geral de Greve reunido na cidade do Rio resumiu-se a aguardar o desenrolar dos acontecimentos, apenas emitindo nota crítica. $^{12}$

Com a palavra de novo, Goulart resolveu apostar alto indicando para presidir o Conselho de Ministros um conservador senador por São Paulo, Auro Moura Andrade, do PSD, que era também o presidente do Senado. Em 2 de julho, a Câmara dos Deputados aprovou o nome de Moura Andrade por esmagadora maioria: 223 votos contra apenas 47 (basicamente dos deputados do PSB e dos setores não fisiológicos do PTB). Embora tivesse firmado alguns acordos com Goulart em sua fala de apresentação à Câmara, o senador pessedista sinalizou que desejava conformar um governo independente do presidente da República, o que provocou reação deste. Em dramático pronunciamento à Rádio Nacional, na noite de 3 daquele mês, Jango afirmou que não iria mais "transigir". ${ }^{13}$

9 "Homenagem a San Tiago Dantas no Sindicato dos Metalúrgicos. Trabalhadores exigem um novo Conselho de Ministros." Bancário, Rio de Janeiro, 13 jun. 1962, n. 34, p. 4. Biblioteca Aloísio Palhano do Sindicato dos Bancários do Rio de Janeiro.

10 A Hora, Recife, 9 a 15 jun. 1962, p. 1 e 7. Hemeroteca do Arquivo Público Estadual de Pernambuco Jordão Emerenciano, Recife (PE).

11 Última Hora, Recife, 29 jun. 1962, p. 2. A Tarde, Salvador, 29 jun. 1962, capa.

12 A nota foi publicada em "Trabalhadores reafirmam: Gabinete nacionalista para solução da crise." 0 Bancário, Rio de Janeiro (GB), 29 jun. 1962, p. 3. Biblioteca Aloísio Palhano do Sindicato dos Bancários do Rio de Janeiro.

13 "Já transigi duas vezes e não pretendo transigir mais. Perdi a paciência." Jornal do Brasil, Rio de Janeiro, 4 jul. 1962, p. 3. 
$\mathrm{Na}$ verdade, desde que negociou a indicação de Moura Andrade, Goulart havia conseguido uma carta de demissão, sem data, mas assinada pelo senador; uma garantia que poderia ser lançada como "carta na manga" caso houvesse alguma "traição". ${ }^{14}$ Não demorou muito para que Goulart percebesse que o prato cozido por Moura Andrade era por demais apimentado. Os primeiros nomes apresentados pelo senador paulista para compor as pastas militares envolviam notórios golpistas, como o almirante Bardi. Em outras áreas, adversários da política externa independente, como Vasco Leitão da Cunha, foram sugeridos para o Ministério das Relações Exteriores. Caso conseguisse emplacar tal gabinete, Moura Andrade consumaria o esvaziamento total dos poderes do presidente João Goulart, consumando uma espécie de "golpe parlamentar". ${ }^{15}$

No meio da tarde daquele dramático 4 de julho, o líder do PTB na Câmara, Almino Afonso, recebeu telefonema do próprio Goulart, onde este lhe pediu para que fosse à tribuna informar da renúncia de Auro Moura Andrade. Foi sob esse clima pesado que o Comando Geral de Greve reuniu-se naquela quarta, dia 4 de julho, no centro do Rio de Janeiro, decidido a desencadear uma ação política que viesse a ser entendida como um posicionamento da classe trabalhadora brasileira na crise política nacional.

\section{No meio do caminho havia uma greve...}

Por volta das $13 \mathrm{~h} 45 \mathrm{~min}$ foi instalada a plenária, e às $15 \mathrm{~h} 30 \mathrm{~min}$ foi decidida greve geral de 24 horas. Entretanto, tão logo se tomou a decisão de decretar a greve, a sede da CNTI começou a ser assediada por emissários de Jango, que transmitiram o pedido do presidente da República para que o movimento fosse suspenso. A questão é que os líderes sindicais só ficaram sabendo da renúncia de Auro Moura Andrade às $16 \mathrm{~h}$, meia hora depois de encerrada sua reunião. Numa reportagem no Correio da Manhã, é possível aferir quão foram pressionados os líderes sindicais:

\footnotetext{
Não sendo bem sucedido nos entendimentos que manteve, pessoalmente, com os grevistas, o sr. Gilberto Crockatt de Sá teve sua missão reforçada pelo presidente do Banco Nacional de Desenvolvimento Econômico [BNDE], o sr. Leocádio Antunes. Este chegou à CNTI por volta das $17 \mathrm{~h}$, mantendo conferências, a portas fechadas, até as 18h45min. O sr. Leocádio Antunes tentou em vão persuadir os articuladores da greve. Travou-se, então, o seguinte diálogo entre a autoridade e o sr. Pelacani, coadjuvado pelo sr. Roberto Morena.

L.A.: Não se justifica o movimento, desde que a situação evoluiu, com a renúncia de Auro.

P.: A sustação da greve desmoralizará (sic) os trabalhadores.

M.: A ordem da greve já está nas ruas e os trabalhadores não poderão compactuar com nova conciliação.
}

14 "O senador Auro Moura Andrade, do PSD, pretendeu, por sua vez, constituir um gabinete de acordo com os líderes de partido, e Goulart, que obtivera previamente uma carta sua de renúncia, fê-la divulgar, antes mesmo que ele assumisse o cargo de primeiro-ministro." BANDEIRA. O governo João Goulart e as lutas sociais no Brasil, 1961-1964, p. 77. Cf. VICTOR, Mário. Cinco anos que abalaram o Brasil. De Jânio Quadros ao marechal Castelo Branco. Rio de Janeiro: Civilização Brasileira, 1965, p. 430-437.

15 MELO. Crise orgânica e ação política da classe trabalhadora brasileira, p. 170. 
L.: Não haverá conciliação, pois o Auro já renunciou. Seu gesto foi consequência da nota do general Osvino e, logo, após, pela ratificação da mesma, pelo general Machado Lopes. O Auro tem um gênio violento, mas se curvou à realidade militar.

P.: Nós queremos a volta do presidencialismo e esta greve tem, como o governo reconhece, outras finalidades. ${ }^{16}$

"Nem Cristo poderá detê-la!", disse Dante Pelacani aos jornalistas presentes na sede da CNTI no final daquela tarde. E, à medida que o tempo passava, em diversos pontos do país, assembleias de trabalhadores endossavam a realização da greve política, tornando o desencadeamento do movimento inevitável.

"Movimento inédito na História do País: Brasil em Greve!"17 Foi assim que o jornal carioca Diário de Notícias apresentou em manchete a greve geral de 5 de julho. $\mathrm{E}$, de fato, seria a primeira vez na história do Brasil que os trabalhadores realizavam uma greve geral nacional. ${ }^{18}$ Digo os trabalhadores enquanto classe social, pois pelo menos algumas categorias já haviam realizado greves nacionais, como os bancários, nos primeiros meses de 1946, e portuários, marítimos e ferroviários na chamada "Greve da Paridade" em 1960. ${ }^{19}$ Nessa última, seria fundado o Pacto de Unidade e Ação (PUA), a primeira intersindical que ultrapassava as barreiras regionais. Assim, bancários e as categorias organizadas no PUA foram as principais a paralisar o trabalho em todas as regiões do Brasil em julho de 1962, embora também encontremos operários metalúrgicos, petroleiros, da indústria têxtil e da construção civil, além de motoristas de ônibus e, no Nordeste, até garçons e músicos pararam de trabalhar naquela quinta-feira.

Na Guanabara e no estado do Rio de Janeiro, a greve foi total, tendo sido acompanhada de ondas de saques na Baixada Fluminense, especialmente em Duque de Caxias, Nova Iguaçu e São João de Meriti, onde o saldo foi de quarenta mortos e setecentos feridos. ${ }^{20}$ Niterói e São Gonçalo também conheceriam distúrbios, assim como alguns subúrbios da Guanabara, como Rocha Miranda, Pavuna, Penha e Brás de Pina. A revolta popular repercutiu em todo o Brasil. É que, durante esse período, graves problemas de desabastecimento atingiam a região, provocando revoltas que compreenderam desde saques de armazéns, empórios, mercadinhos até o "justiçamento" de comerciantes, acusados pelos populares de estarem sonegando alimentos.

De acordo com o historiador José Cláudio Souza Alves, embora não possamos encontrar qualquer indício de que a onda de saques não tenha sido eminentemente espontânea, a greve geral teve uma ligação direta com os acontecimentos na

16 Correio da Manhã, Rio de Janeiro, 5 jul. 1962, p. 1.

17 Diário de Notícias, Rio de Janeiro, 5 jul. 1962, p. 1.

18 MELO. Crise orgânica e ação política da classe trabalhadora brasileira, p. 156-212.

19 Um apanhado geral sobre esse ciclo de greves, ver TELLES, Jover. O movimento sindical no Brasil. Rio de Janeiro: Vitória, 1962. MIGLIOLI, Jorge. Como são feitas as greves no Brasil? Rio de Janeiro: Civilização Brasileira, 1963. HARDING, Timothy Fox. The political history of organized labor in Brazil. (Ph.D. dissertation, Stanford University Press, 1973). ERICKSON, Kenneth Paul. Sindicalismo e processo político no Brasil. São Paulo: Brasiliense, 1979, p. 138-203. DELGADO, Lucília Almeida Neves. O Comando Geral dos Trabalhadores no Brasil (1961-1964). Petrópolis: Vozes, 1986. MATTOS, Marcelo Badaró. Trabalhadores e sindicatos no Brasil. São Paulo: Expressão Popular, 2009, p. 77-100.

20 Todas as informações sobre essa greve na cidade do Rio de Janeiro e no estado do Rio foram colhidas nas seguintes fontes: O Globo, Rio de Janeiro, 5 e 6 jul. 1962; O Dia, Rio de Janeiro, 5 e 6 jul. 1962. Jornal do Brasil, 5 e 6 jul. 1962; Correio da Manhã, Rio de Janeiro, 5, 6 e 7 jul. 1962; Última Hora, Rio de Janeiro, 4, 5 e 6 jul. 1962; Luta Democrática, Rio de Janeiro, 3, 4, 5 e 6 jul. 1962; "5 de julho: o País parou em grandiosa greve política da classe operária." Novos Rumos, Rio de Janeiro, 12 jul. 1962, p. 2.; "Flagrantes da Greve." 0 Bancário, Rio de Janeiro (GB), 11 jul. 1962, p. 3. Biblioteca Aloísio Palhano do Sindicato dos Bancários do Rio de Janeiro. 
Baixada Fluminense no dia 5 de julho, pois milhares de populares que, vindos de bairros afastados de Caxias se aglomeraram na área próxima à Praça do Pacificador, no centro do município, desejavam chegar aos seus locais de trabalho, mas não havia transportes públicos em decorrência da greve. ${ }^{21}$ Aglutinando cerca de 20 mil pessoas, bastou que um dos populares começasse a gritar que havia feijão em uma das casas comerciais da localidade, para que a multidão, em fúria, saqueasse o armazém e iniciasse uma onda de saque e destruição de outros armazéns, açougues e padarias. Ao meio-dia, todo o comércio do centro de Caxias havia sido atingido, e por essa hora a revolta já havia se alastrado para as cidades vizinhas de São João de Meriti e Nova Iguaçu. Alguns comerciantes que, desesperados, tentaram defender suas propriedades, foram mortos pela fúria da população, chegando, alguns, a sacar armas e atirar contra os revoltosos, que também tiveram suas baixas. Outra relação entre esse motim e a greve política deve-se ao fato de que estabelecimentos comerciais que haviam hasteado em suas fachadas a bandeira brasileira e dizeres em apoio à legalidade democrática foram poupados. ${ }^{22}$

No que diz respeito à greve propriamente dita, a categoria dos ferroviários da Estrada de Ferro Leopoldina foi a primeira a paralisar suas atividades, por volta das 19h35min do dia 4 de julho. O ramal paralisado envolvia os estados de São Paulo, Rio de Janeiro, Guanabara e Espírito Santo. Às 23h3omin, o comando de greve dos ferroviários divulgaria um boletim onde eram afirmados os motivos da greve e a advertência de que ela deveria durar até às $24 \mathrm{~h}$ do dia 5 . As barcas que ligam a cidade do Rio a Niterói e ilhas próximas tiveram seu serviço suspenso à zero hora do dia 5, e às primeiras horas da manhã do dia deixaram de circular os bondes e os ônibus, estes últimos também por iniciativa das empresas, temerosas da ação dos piquetes.

Ainda na noite do dia 4, centenas de ativistas sindicais compareceram à sede do Sindicato dos Bancários da Guanabara para constituir comissões de organização e divulgação, que confeccionaram centenas de cartazes da greve, os quais depois seriam colados, ao longo da madrugada, nas portas das agências. Naquele dia 5 de julho, esse muito bem organizado sindicalismo bancário combateu nas ruas do centro do Rio pela vitória da greve e contra a repressão desencadeada pela Polícia Política e Social do governo da Guanabara, tendo inclusive o próprio governador Carlos Lacerda realizado incursão ao centro do Rio, ladeado por policiais, com o propósito de dispersar os piquetes de greve, prender ativistas e reabrir agências bancárias. Segundo reportagem do jornal O Dia, às 8 h da manhã o DOPS já começou a realizar detenções nos piquetes, e Lacerda, armado com uma metralhadora, ia rasgando os cartazes da greve, ao mesmo tempo em que ameaçava enquadrar os grevistas na Lei de Segurança Nacional. As poucas agências que a tropa de Lacerda conseguiu abrir logo fecharam após a sua saída. O governador chegou mesmo a bater boca com sindicalistas, tendo sua polícia realizado dezenas de detenções. Conforme relato do periódico sindical:

De repente surgiu o sr. governador no centro da cidade. Saltava de seu luxuoso automóvel acompanhado de um pequeno batalhão fortemente armado com bombas e metralhadoras portáteis. Para arrancar os

21 Todas as informações a seguir foram retiradas de ALVES, José Cláudio Souza. Dos barões ao extermínio: uma história da violência na Baixada Fluminense. Duque de Caxias: APPH-CLIO, 2003, p. 93-95. TORRES, Rogério; MENEZES, Newton. Sonegação Fome Saque. Duque de Caxias: Consórcio de Administração de Edições, 1987. CATALEJO, Manoel Henrique de Souza. O município de Duque de Caxias e a ditadura militar: 1964-1985. (Dissertação de mestrado em História, Universidade Federal do Rio de Janeiro, 2008), p. 57-65.

22 MELO. Crise orgânica e ação política da classe trabalhadora brasileira, p. 181-182. 
cartazes mais altos dava os característicos pulinhos, que comprometiam seriamente a postura governamental. Esbravejava impropérios, era apupado, efetuou prisões. Foi tratado por alguns companheiros como merece um governador que desce de suas funções para substituir os tiras da Ordem Política e Social..$^{23}$

Um desses casos de prisão que ganhou notoriedade entre os dirigentes sindicais cariocas foi o de um personagem de nome Cainã Costa Pereira, funcionário da Federação dos Bancários do Rio de Janeiro e Espírito Santo, que se enfrentou com o próprio Lacerda "no braço", apesar de ser magrinho. De acordo com algumas versões, alguém, provavelmente o próprio Cainã, teria desferido um golpe certeiro na nádega do governador Carlos Lacerda, iniciando o tumulto que resultou na sua prisão. ${ }^{24}$

No setor têxtil da zona industrial do Rio diversas empresas amanheceram paralisadas, o mesmo acontecendo com grandes empresas do setor gráfico, metalúrgico, de material elétrico, de calçados e os estaleiros da construção naval. As refinarias de Manguinhos e Duque de Caxias também foram atingidas pelo movimento paredista, e a greve geral no sistema de transportes atingiu até o sistema hospitalar carioca, ainda que o Comando de Greve não tivesse orientado qualquer paralisação no setor. As entidades associativas de professores e dos servidores públicos também divulgaram manifestos de adesão à greve geral, tendo o sindicato do magistério feito questão de destacar que a autoridade política para a entidade decretar a greve da categoria havia sido estabelecida em assembleia geral realizada no sindicato, em 26 de junho. Por fim, o Sindicato dos Trabalhadores na Indústria do Gás e Energia Elétrica decidiu que, caso a greve fosse estendida para além das $24 \mathrm{~h}$, o setor iria aderir.

Enquanto a greve se desenrolava no Rio de Janeiro e em outras cidades do país, uma comissão de líderes sindicais encaminhou-se para Brasília, com o objetivo de manter conversações com João Goulart sobre a crise política nacional e as reivindicações da greve. Dessa reunião também teriam tomado parte o general Amaury Kruel, Hermes Lima (PSB-BA) e o consultor geral da República, Antônio Balbino (PSD-BA). Fizeram parte da comissão Dante Pelacani (vice-presidente em exercício da CNTI), o líder bancário Luís Viegas Motta e Lima (representando a Contec) e o portuário Osvaldo Pacheco (pelo PUA). Como os aeronautas e aeroviários também se encontravam em greve, o CGG teve de enviar um ofício ao Sindicato dos Aeronautas, à Panair do Brasil e ao Ministério da Aeronáutica pedindo a liberação de um avião, que transportou as lideranças ao Distrito Federal.

Ao longo da tarde, chegariam notícias sobre a efetividade da greve em todas as regiões do Brasil, além dos lugares onde a parede não tinha conseguido grande adesão, como na capital paulista e em Minas Gerais. Já no sul do país, as senhas para a greve demoraram a chegar, atrasando os entendimentos entre o comando nacional e os dispositivos grevistas regionais, o que acabou atrasando a eclosão da greve geral em um dia. Por volta das $17 \mathrm{~h}$ daquele dia 5 , chegou à sede da CNTI o presidente da UNE, Aldo Arantes, e às 17h45min, os líderes grevistas se avistaram com Goulart em Brasília. Entrando prontamente em reunião com os demais presentes, fechada à imprensa e até aos funcionários da própria entidade, o Comando Geral de Greve avaliou o sucesso da greve nacional. Às 2oh, Roberto Morena abriu a porta da sala exclamando: "A greve está plenamente vitoriosa!"

23 "Flagrantes da Greve".

24 Entrevista nossa com Luiz Viegas da Motta Lima. 27 jan. 2012. 
Logo em seguida, foi iniciada uma assembleia com mais de uma centena de líderes sindicais que acabaram por decidir a suspensão da greve à zero hora do dia 6, seguindo o pedido do presidente Goulart.

Ao longo do dia 5, líderes sindicais de outras regiões do Brasil haviam voltado às suas bases locais para participar (e dirigir) o movimento grevista. Vejamos como se processou a greve no restante do país.

\section{A greve geral no Brasil}

Entre $16 \mathrm{~h}$ e $17 \mathrm{~h}$, da sede da CNTI, no Rio de Janeiro, o Sr. Wilson de Barros Leal telefonou aos estados para acionar o dispositivo grevista por meio da "senha". Sua mensagem foi recebida com maior entusiasmo em alguns estados nordestinos. ${ }^{25}$ Na capital pernambucana, o Consintra realizou uma reunião já às 17h do dia 4, logo após ter sido recebida a tal "senha", na qual foi decidida a imediata decretação da greve geral e a orientação para que os sindicatos aprovassem a medida em suas assembleias já nas primeiras horas da noite daquele dia. Às 22h, inúmeras entidades classistas pernambucanas já haviam distribuído manifestos conclamando a greve geral, desde bancários até trabalhadores da orla marítima.

Na manhã do dia 5, o líder ferroviário Cláudio Braga, presidente do Consintra (presente no dia anterior na reunião da CNTI no Rio de Janeiro), chegava ao Aeroporto dos Guararapes, sendo recepcionado por uma comitiva de sindicalistas que o encaminhou ao comando de greve. Como parte da comitiva estavam os presidentes dos sindicatos da orla marítima, como o portuário Cícero Targino Dantas e o estivador José Osvaldo Gomes, o que denotava o grau de articulação entre as categorias agrupadas no PUA.

A imprensa pernambucana assinalou a paralisação total da rede bancária que compreendia a base sindical da Federação Norte e Nordeste dos Bancários, desde Alagoas até Manaus. A própria Federação determinou a greve em toda sua jurisdição, tendo seu presidente, Gilberto Azevedo, ao lado do presidente do Sindicato dos Bancários de Pernambuco, Fausto Nascimento, tomado a iniciativa de informar aos gerentes das agências bancárias pernambucanas a decisão dos trabalhadores de realizar a greve política.

Em Pernambuco, foi total a paralisação dos trabalhadores da orla marítima e da Rede Ferroviária do Nordeste, cujo ramal compreendia os estados de Alagoas, Pernambuco, Paraíba e Rio Grande do Norte. Em Recife, 8 mil trabalhadores da zona portuária cruzaram os braços deixando 23 navios parados (treze atracados e dez ao largo). Pararam também os moageiros, ao meio-dia no Moinho Recife e na Fábrica de Massas Alimentícias Pilar, movimento dirigido que acabou prejudicando o próprio funcionamento das padarias. Os rodoviários recifenses começaram a paralisar seu trabalho às $15 \mathrm{~h}$, tendo às $20 \mathrm{~h}$ cessado totalmente o sistema de transportes públicos na capital. Os voos do Rio para Recife e Fortaleza também foram cancelados, e os telegrafistas fizeram uma "operação tartaruga". Estudantes também se juntaram a trabalhadores e promoveram piquetes em portas de fábricas e estabelecimentos comerciais, realizando pequenos comícios com o propósito de persuadir os trabalhadores a aderirem à greve geral.

25 As informações sobre a greve geral na região Nordeste foram colhidas nas seguintes fontes: Diário de Pernambuco, Recife, 5 e 6 jul. 1962; Última Hora, Recife, 4, 5 e 6 jul. 1962; "Vitória dos trabalhadores na greve de advertência." A Hora, Recife, 30 jun. a 7 jul. 1962, p. 2; Correio do Ceará, Fortaleza, 6 jul. 1962; 0 Povo, Fortaleza, 5 e 6 jul. 1962; A Tarde, Salvador, 5 e 6 jul. 1962. 
Em Fortaleza, a greve também foi geral. Bancos, comércio, o Porto de Mucuripe, a Rede de Viação Cearense, repartições públicas e transportes urbanos pararam. Na parte da manhã do dia 5, comerciantes de Fortaleza tentaram abrir seus estabelecimentos, mas ficaram surpresos pois "as fechaduras das portas estavam obstruídas e, em muitos casos, havia cadeados novos, tudo feito pelos grevistas". Com isso, "tornou-se impraticável o funcionamento do comércio, que, assim, permaneceu de portas cerradas durante todo o dia." 26

De acordo com a folha cearense $O$ Povo, às $11 \mathrm{~h}$ do dia 5 , se encontravam paralisadas as fábricas têxteis Santa Cecília e Santa Maria, além das plantas da São Judas Tadeu, Cidão e Usina Everest. Além disso, a Siqueira Gurgel S.A. encontravase parcialmente paralisada; contudo, outras cinco importantes empresas estavam com o funcionamento normal. ${ }^{27}$ Os ferroviários cearenses iniciaram a greve à zero hora do dia 5, tendo paralisado todos os setores da Rede de Viação Cearense, exceto o serviço telegráfico, que ficou funcionando parcialmente e sob o controle do comando grevista. A greve dos ferroviários contou também com o apoio dos engenheiros da empresa.

Já a greve dos bancários contou com a colaboração de alguns gerentes bancários e também com o apoio explícito do presidente da Caixa Econômica Federal no Ceará, Luís Campos, que declarou à imprensa estar totalmente solidário com o "movimento dos trabalhadores pela legalidade". A greve dos trabalhadores do porto também teve seus momentos de radicalização quando, também na parte da manhã, os grevistas chegaram a forçar a atracação de um barco que tentou abandonar o ancoradouro. Era o sinal de que o movimento de greve não aceitaria nenhuma indisciplina. Por sua vez, temendo a proliferação de quebra-quebras, os donos das frotas de transportes públicos retiraram os ônibus de circulação das $9 h$ às $10 \mathrm{~h}$ da manhã, já que, por essa hora, manifestantes estavam parando os veículos e obrigando os poucos passageiros a descerem.

Às 10h3omin, um grupo de centenas de trabalhadores da orla marítima se deslocou para a Praça Valdemar Falcão, onde confraternizou com representantes de outras categorias de grevistas que faziam agitação através de um sistema de som. Decidiram sair em passeata pela Rua Senador Alencar, tomando a Rua 24 de Maio em direção à Praça José de Alencar. Nesse local se realizou um "comício relâmpago", assim como em outras ruelas do centro de Fortaleza.

De passagem pela capital cearense, durante a parte da manhã, o presidente do Sindicato Nacional dos Aeroviários, Elício Sérgio de Melo, declarou aos repórteres que a greve era total em toda a região Nordeste. ${ }^{28} \mathrm{~A}$ verdade é que, mesmo na região nordestina, o movimento não era total.

Na Paraíba, os sindicatos decretaram estado de alerta e a Federação dos Trabalhadores na Indústria convocou uma assembleia geral permanente. Houve ainda uma concentração popular nas ruas centrais da capital paraibana, nas imediações da Praça João Pessoa, onde os populares aguardavam o desenrolar dos acontecimentos. Por sua vez, o governador Pedro Godim emitiu nota se solidarizando com Goulart. No Maranhão, foi paralisada a linha férrea que ligava São Luís à capital do Piauí, Teresina. Já na Bahia, a Petrobras e o porto paralisaram suas atividades no dia 5 de julho, mas não se viu nenhuma outra adesão.

Na região Norte, no Pará, os primeiros a entrar em greve foram os funcionários 
da Petrobras. O seu Sindicato dos Trabalhadores na Indústria da Extração do Petróleo, cuja base abrangia os estados do Pará, Amazonas e Maranhão, publicou no jornal A Província do Pará uma nota conclamando à greve geral. Nessa nota, a greve é apresentada como um movimento contra o imperialismo norte-americano, em defesa da Petrobras, por Jango e por um gabinete nacionalista capaz de realizar as reformas de base. ${ }^{29}$ Nessa categoria, a adesão foi total. O segundo setor a paralisar totalmente foi dos marítimos e portuários. Já a Federação dos Trabalhadores na Indústria do Pará não decretou greve, mas ficou de sobreaviso esperando o desenrolar dos acontecimentos. Diferentemente de outras regiões, os bancários também não paralisaram, embora o seu sindicato tenha se colocado em solidariedade a Jango. Também as escolas, os escritórios e o Instituto de Previdência Social funcionaram com enorme irregularidade.

Voltando à região Sudeste, nos estados de Minas e São Paulo a paralisação foi parcial. Em Minas, houve greve na companhia siderúrgica Mannesmann (em Belo Horizonte) e na Cidade Industrial (Contagem), com depredações em Além Paraíba. De acordo com $O$ Estado de Minas, na Mannesmann, pelotões de paredistas "se postaram nos dois portões de acesso às oficinas da empresa" impedindo a entrada dos funcionários que compareceram para trabalhar. $\mathrm{O}$ mesmo dispositivo teria sido utilizado pelos grevistas na Magnesita S.A., localizada na Cidade Industrial, mas os resultados não seriam muito alvissareiros. No restante do estado mineiro, o movimento grevista parece não ter tido maiores repercussões. ${ }^{30}$

$\mathrm{Na}$ capital paulista, a greve foi um fracasso total. Dado o significativo grau de ativismo do movimento sindical paulistano, e onde era notável a presença da esquerda, ${ }^{31}$ a ausência da cidade no computo geral do movimento paredista certamente indica sua debilidade. A questão decisiva estava na relação de forças específicas. Para ser bem sucedida, a greve em São Paulo teria que ser capaz de enfrentar-se com a associação entre a classe patronal e o governo estadual. Pois, já na tarde do dia 4, logo que ficaram sabendo da orientação emanada da CNTI para uma greve geral em todo o país, os mais importantes industriais paulistas pediram uma audiência com o governador Carvalho Pinto para que fossem tomadas providências. Liderados pelo empresário José Ermírio de Moraes Filho, os industriais da FIESP tão somente pediram ao governador que acionasse o dispositivo da DOPS. ${ }^{32}$

Por outro lado, se com essa articulação foi possível deter a greve política na capital, a paralisação foi total em Santos (portos, fábricas, oficinas, funcionalismo, operários da refinaria de (ubatão), São Vicente e demais cidades da Baixada Santista. ${ }^{33} \mathrm{O}$ muito bem articulado Fórum Sindical de Debates (FSD) de Santos,

29 "Trabalhadores em greve: país vai parar." Província do Pará, Belém, 5 jul. 1962, p. 5.

30 "Sem extensão a greve na capital." e "Suspensão da greve à zero hora de hoje." O Estado de Minas, Belo Horizonte, 6 jul. 1962, capa e p. 5.

31 Cf. PEREIRA NETO, Murilo Leal. A reinvenção da classe trabalhadora (1953-1964). Campinas: Ed. Unicamp, 2011.

32 "Calma em São Paulo." Correio Paulistano, São Paulo, 5 jul. 1962, p. 6. Carvalho Pinto tinha experiência na repressão ao movimento sindical paulista, pois em dezembro do ano anterior, ao lado dos ministros da Justiça, Alfredo Nasser, e do Trabalho, Franco Montoro, coordenou a brutal repressão ao movimento operário paulista que organizou uma greve geral em 13 de dezembro para pressionar o Senado para que este aprovasse o projeto de lei, já votado pela Câmara, que instituía o $13^{\circ}$ salário. Em uma nota oficial expedida no dia 12 de dezembro de 1961, um dia antes da programada greve geral pelo $13^{\circ}$, o ministro da Justiça declarou que "O Congresso Nacional não decide sob coação". Isso foi escrito pouco mais de dois meses após, sob coação do golpismo militar, o Congresso ter emendado a Constituição para instituir o parlamentarismo. "Ministro da Justiça declara ilegal a anunciada greve", Folha de São Paulo, 13 dez. 1961, p. 1. Sobre o fracasso dessas greves políticas em São Paulo, cf. PEREIRA NETO, A reinvenção da classe trabalhadora, p. 301-303.

33 Sobre a greve na Baixada Santista, as informações foram colhidas em: SARTI, Ingrid. Porto Vermelho: os 
intersindical horizontal fundado em 1956 e que congregava a totalidade dos 56 sindicatos de Santos e de outras cidades da Baixada Santista, possuía um exemplar trabalho político com suas bases, tendo já uma experiência de muitas lutas importantes.

O FSD reuniu-se no início da noite do dia 4 de julho na sede do Sindicato dos Operários Portuários, onde proclamaram a greve geral. Em Santos, o movimento iniciou-se logo na noite do dia 4 na Refinaria Presidente Bernardes, seguindo com a paralisação da principal atividade econômica da cidade, o porto e de toda a orla marítima - já à zero hora do dia 5 -, tendo a própria Companhia Docas de Santos deliberado a suspensão oficial dos trabalhos nas primeiras horas da manhã. A sede do Sindicato dos Portuários foi transformada em "quartel-general" da greve, de onde partiram uma série de piquetes antes da zero hora do dia 5.

Atendendo ao pedido de uma comissão de representantes sindicais, a Secretaria Municipal de Transportes Coletivos decidiu tirar os seus bondes e ônibus de circulação, tendo o mesmo sido feito pelas empresas particulares, e até o serviço de táxis foi suspenso, já que os piquetes grevistas também molestaram os motoristas que insistiam em trabalhar. Até as empresas que operavam a linha intermunicipal para a capital do estado suspenderam totalmente suas atividades às $14 \mathrm{~h}$, tendo funcionado de forma bastante precária nas horas anteriores.

A única linha da Rede Ferroviária Nacional no estado de São Paulo a entrar em greve foi a Estrada de Ferro Santos-Jundiaí, onde, às 16h, como forma de socorrer os populares perdidos nas estações ferroviárias, caminhões do Departamento de Estradas de Rodagem e da Estrada de Ferro Sorocabana foram requisitados pela Secretaria Estadual de Segurança para transportar os populares de volta para seus lares. Todos os bares e restaurantes do centro comercial de Santos também não funcionaram. Além das fábricas, o comércio cerrou suas portas e nem as escolas funcionaram, pois o ativo movimento estudantil secundarista puxou a greve. Com medo dos piquetes, até as salas de cinema do centro da cidade suspenderam suas tradicionais sessões vespertinas.

No vizinho Paraná, também havia um Fórum Sindical de Debates do Litoral Paranaense, fundado naquele mesmo ano de 1962, por iniciativa dos trabalhadores que trabalhavam no Porto de Paranaguá, e que foi o único setor daquele estado que paralisou suas atividades na greve geral em apoio ao presidente João Goulart. ${ }^{34}$

Já no Rio Grande do Sul, não obstante o alto grau de articulação do movimento sindical, a demora da chegada das senhas na noite do dia 4 acabou por prejudicar a eclosão do movimento grevista de forma simultânea ao que ocorreu em todo o país no dia 5 de julho. Em face desse atraso, reunido na ocasião na sede do Sindicato dos Gráficos, o Comando Sindical gaúcho decidiu organizar a paralisação para o dia 6.35 Presentes nessa reunião estavam os representantes sindicais da orla

estivadores santistas no sindicato e na política. Rio de Janeiro: Paz e Terra, 1981, p. 132-134. SILVA, Fernando Teixeira da. A carga e a culpa: os operários das Docas de Santos: direitos e cultura da solidariedade (19371968). São Paulo: Hucitec; Santos: Prefeitura Municipal de Santos, 1995, p. 177. "Decretada greve geral em toda a Baixada Santista a partir da zero hora de hoje." A Tribuna de Santos, Santos, 5 jul. 1962, p. 8. "Santos totalmente parada pela greve geral de ontem." Correio Paulistano, São Paulo, 6 jul. 1962, p. 3.

34 "Greve em Paranaguá: sindicatos organizam movimento antigolpista e de apoio a Jango!" Última Hora, Curitiba, 6 jul. 1962, p. 2.

35 Sobre a greve na região Sul, as informações foram levantadas nas seguintes fontes: JAKOBY, Marcos André. A organização sindical dos trabalhadores metalúrgicos de Porto Alegre no período de 1960 a 1964. Dissertação de mestrado em História. UFF, 2008, p. 146-147. SANTOS, João Marcelo Pereira dos. Herdeiros de Sísifo. Ação coletiva dos trabalhadores porto-alegrenses nos anos 1958 a 1963. Dissertação de mestrado em História. Campinas, Unicamp, 2002. "Sindicatos do RGS: só amanhã a greve." Diário de Notícias, Porto Alegre, 5 jul. 1962, p. 1. "Greve no Estado começou quando findou a Nacional." Diário de Notícias, Porto 
marítima, portuários, energia elétrica, telefones, metalúrgicos, ferroviários, fiação e tecelagem, transviários, bancários, além dos gráficos e outras categorias. Em assembleia permanente, deliberaram também uma reunião para a tarde do dia 5, na sede do IAPI, de modo a acompanhar os acontecimentos e organizar sua própria paralisação, mas o Comando acabou mesmo por ficar reunido no Sindicato dos Gráficos.

Entretanto, no final da tarde do dia 5, representantes do Comando Sindical foram chamados pelo governador Leonel Brizola ao Palácio Piratini. Lançando mão do seu prestígio, Brizola insistiu para que o movimento não fosse deflagrado no estado, mas obteve resposta negativa por parte do Comando, apesar de ter sido acertado que não seriam paralisados os serviços essenciais. $O$ governador Brizola continuaria a tentar sustar o movimento na tarde do dia 6 , quando telefonou para o "QG" da greve no Sindicato dos Gráficos e, em contato com o presidente do Comando, Luiz Vieira da Silva, tentou persuadir os sindicalistas a suspender a paralisação. Todavia, na rápida reunião que se seguiu ao telefonema, embora os presentes reconhecessem no governador gaúcho, como também no presidente Jango, as qualidades de "amigos dos operários", a greve foi mantida, pois, alegou-se, se tratava de seguir a orientação emanada da CNTI. Na ocasião, embora ponderadas, também não faltaram críticas ao governador Brizola e ao próprio Goulart, como a feita pelo sindicalista gráfico Assis Brasil Albuquerque, que pontuou que os dois líderes trabalhistas tomavam "muitas atitudes esquecendose, ambos, de consultarem as classes trabalhadoras", referindo-se claramente ao que havia sido até então as negociações para a escolha da composição do novo Conselho de Ministros. E que o governador gaúcho também só lembra de conversar com os trabalhadores "quando Ihe interessa", ironizou.

No dia 6, a cidade de Porto Alegre ficou deserta. O comércio e as agências bancárias do centro da cidade não funcionaram, nem bares, restaurantes, armazéns e supermercados, que mantiveram suas portas cerradas por todo o dia. Além disso, também aderiram à greve os trabalhadores em energia, ferroviários, transviários, motoristas (inclusive de táxis), gráficos, metalúrgicos, marítimos, empregados em serviços telefônicos e trabalhadores de toda a área industrial.

Os que se aventuraram a ir ao trabalho nesse dia, acreditando provavelmente que os sindicalistas seguiriam os apelos do presidente Goulart, encontraram o sistema de transportes porto-alegrense totalmente paralisado. E, após as 10h da manhã, até a rodoviária da capital fechou suas portas, combinando-se à paralisação geral da rede ferroviária que havia suspendido seus serviços desde a zero hora do dia 6 . Em relação às ferrovias, uma comissão de líderes, tendo à frente João Batista Pilar (presidente da Associação dos Ferroviários Riograndenses) e Ruy Yung (do Conselho Sindical Gaúcho), informou ao diretor-superintendente da Viação Férrea, Vicente Cortazzi, sobre o desencadeamento do movimento. E este, por sua vez, afirmou estar solidário ao movimento, repetindo uma atitude de gestores de empresas públicas verificada em outros pontos do país. Apenas os funcionários do Aeroporto Salgado Filho não aderiram à greve, embora a paralisação total dos transportes tivesse prejudicado a locomoção de passageiros e da tripulação em sua direção.

Já em Santa Catarina, a greve foi, tal como no Rio Grande do Sul, no dia 6, também em razão do atraso na chegada das "senhas". Por determinação dos

Alegre, 6 jul. 1962, p. 9 e 13. "Greve interrompida ontem à meia-noite: sindicatos vão decidir (Pelotas) se continua." Diário de Notícias, Porto Alegre, 7 jul. 1962, p. 9. "Greve (ordeira) interrompida à zero hora de hoje: cidade quase ficou deserta", Diário de Notícias, Porto Alegre, 7 jul. 1962, p. 9. "RGS em greve até segunda ordem." Diário de Notícias, Porto Alegre, 6 jul. 1962, p. 1. 
sindicatos e federações sindicais estaduais, pararam os estivadores e conferentes dos portos de Itajaí e São Francisco do Sul, além dos rodoviários da capital e trabalhadores da área industrial.

\section{A importância da greve no quadro da crise política}

Embora Goulart tenha ficado contra a deflagração da greve, não há dúvida de que ela foi feita em seu apoio e lhe beneficiou. Indicando pela terceira vez um nome para presidir o Conselho de Ministros, o escolhido estava entre os homens do governo gaúcho, o jurista Brochado da Rocha, personagem que havia tido atuação importante nos processos de encampação de empresas estrangeiras protagonizado por Leonel Brizola. Jango pôde indicar esse nome, formalmente alegando ser o mesmo pertencente ao PSD (a maior legenda no Parlamento federal), dobrando o Congresso com um nome inexpressivo. A greve geral de 5 de julho certamente contribuiu para que Goulart afinal conseguisse impor um gabinete de sua confiança, dando um passo decisivo na sua empreitada de conquistar os poderes do presidencialismo.

A notícia sobre o desenrolar da greve em várias capitais do Brasil adentrou os muros do Legislativo federal, como se pode ver no pronunciamento de Breno da Silveira (PSB-GB), que além de pontuar a ocorrência de saques e depredações ocorridas na Baixada Fluminense, mencionou que:

(...) notícias que nos chegam ao conhecimento revelam que vêm eclodindo greves em vários estados do País. Cumpre, assim, a classe trabalhadora as promessas feitas caso esta Casa não tomasse providências positivas e urgentes, no sentido de uma solução à crise de abastecimento, realmente a mais dura que atravessam as classes menos favorecidas.

Esses acontecimentos vêm [se] agravando sempre nos últimos meses. No estado do Rio já se verificam depredações e assaltos, com saques. ${ }^{36}$

Mas a greve geral também afetou diretamente a vida de senadores e deputados federais das bancadas direitistas da UDN e PSD, muitos dos quais se viram impedidos de voltar aos seus estados de origem em razão da paralisação da aviação comercial em grande parte do país, ficando "presos" em Brasília. Um desses casos encontra-se em um relato de uma reunião de balanço da greve na sede do Sindicato dos Bancários da Guanabara, constante em um documento produzido pela Polícia Política, ${ }^{37}$ e teria sido protagonizado pelo senador pela UDN de São Paulo, padre Calazans, apelidado pelas esquerdas de "Carlos Lacerda do Senado". Ao avistar a comissão de sindicalistas que havia ido ao Distrito Federal reunir-se com Jango na manhã do dia 5 - a tal comissão do CGG -, Calazans ficou a esbravejar palavras chulas e dizeres como "em São Paulo a greve não colou!"

A greve também foi notada com atenção pelo embaixador Lincoln Gordon e pela própria $\mathrm{CIA}$, como um episódio que favoreceu Goulart. No caso do embaixador, já no dia 6 de julho, este enviou telegrama ao secretário de Estado, Dean Rusk, no

36 Diário do Congresso Nacional, Brasília, Seção I, 6 jul. 1962, n. 3955, p. 7.

37 Trata-se de um Boletim Reservado, que se constitui num relato quase diário das atividades do movimento operário e sindical investigado pelo Departamento de Polícia Política e Social (DPPS) da Guanabara, e está depositado encadernado no Fundo Polícias Políticas do Arquivo Público do Estado do Rio de Janeiro (APERJ). O episódio relatado encontra-se em: Boletim Reservado, n. 115, 9 jul. 1962. Fundo Polícias Políticas, APERJ. 
qual reconhecia que "O Congresso [estava] completamente desmoralizado pela demonstração [da] habilidade de João Goulart [de] organizar os trabalhadores em seu apoio [na] forma [de] greve geral." Poucos dias depois, num relatório da $\mathrm{CIA}$, classificado como ultrassecreto ("Top Secret") e datado de 13 de julho de 1962, a greve de julho é apresentada como um movimento organizado pelos comunistas, que atingiu diversas cidades importantes e "proporções inéditas na história do Brasil".

Organizações trabalhistas sob a considerável influência comunista convocaram uma greve de 24 horas nas principais cidades em todo o Brasil, em apoio a Goulart. As greves foram difusas, mas impressionantes para os padrões brasileiros. ${ }^{38}$

Ao contrário do que sugere essa visão, a greve não pode ser entendida como um movimento no exclusivo interesse de elites políticas e descolado dos interesses materiais da classe trabalhadora. Afinal, o mesmo foi também capaz de arrancar a aprovação da lei que instituiu o $13^{\circ}$ salário, quando, alguns dias depois, em 13 de julho - mesmo dia em que a Câmara aprovou Brochado da Rocha como premier -, Goulart sancionou esse simbólico direito trabalhista. É claro que tal lei não foi o resultado dessa greve, mas de uma longa cadeia de mobilizações que a classe trabalhadora brasileira travou em décadas e cuja gênese esteve ligada à reivindicação de um rendimento extraordinário para o fim de um longo ano de trabalho árduo; em seguida, reivindicação de sindicatos, motivo de protestos, abaixo assinados, reuniões públicas e greves, das quais a de 5 de julho de 1962 foi um momento culminante.

Além disso, outro ganho significativo resultante da greve se daria no nível organizativo, pois a partir da experiência da greve geral seria conformado o Comando Geral dos Trabalhadores (CGT) em agosto daquele ano. Tal entidade daria maior coordenação nacional ao movimento sindical brasileiro, desafiando os preceitos corporativistas da legislação vigente que impedia a formação de centrais sindicais no Brasil, embora isso fosse feito a partir da influência que a esquerda possuía na estrutura oficial, incorporando-a em parte. ${ }^{39}$

\section{Considerações finais}

Um mês depois de sua fundação, o CGT convocaria novamente uma greve geral política, também bem sucedida do ponto de vista político, pois mais uma vez serviu para pressionar o Congresso a atender as exigências políticas de Goulart, no caso, a aprovação de uma emenda à lei que instituiu o parlamentarismo, determinando a realização de um plebiscito em 6 de janeiro do ano seguinte. Além de ajudar Jango a fechar as contas do parlamentarismo, essa segunda greve geral também arrancou do governo compromissos com o reajuste do salário mínimo. ${ }^{40}$

38 "Organized labor under considerable Communist influence called 24-hour strikes in major cities throughout Brazil in support of Goulart. The strikes were scattered but impressive by Brazilian standards and hence politically effective." Central Intelligence Agency. Office of Current Intelligence. Current Intelligence Weekly Review. 13 de julho de 1962, p.25. Disponível em https://www.cia.gov/ . O telegrama de Gordon é citado em DREIFUSS, René Armand. 1964, a conquista do Estado: ação política, poder e golpe de classe. Petrópolis: Vozes, 1981, p. 260.

39 DELGADO, O Comando Geral dos Trabalhadores.

40 Sobre a greve geral de 14-16 de setembro de 1962, cf. ERICKSON. Sindicalismo e processo político, p. 154-158. 
Após essas experiências bem sucedidas em 1962, o CGT voltaria a levantar a palavra de ordem da greve geral política. Mas recolheu a bandeira a cada aceno positivo de Goulart, até que em 31 de março de 1964 - quando as tropas do general Mourão estavam a caminho da Guanabara - voltaria a convocá-la pela última vez. Ao contrário das greves gerais de 1962, a de 1964 não teve eficácia política, como de resto todas as formas de resistência ao golpe de Estado que falharam. Olhando toda a cena desenrolada, podemos concluir que a greve geral de 5 de julho de 1962 significou um ponto de inflexão na relação de forças no contexto do governo João Goulart. Efetivamente, o episódio o favoreceu.

O fortalecimento da capacidade política das organizações trabalhistas e do grau de legitimidade delas junto a suas bases sociais - decorrentes das conquistas materiais efetivas no que concerne aos seus direitos, especialmente $013^{\circ}$ salário teve na greve geral em tela um marco. A derrota histórica em 1964 interromperia esse rico processo de construção da participação política dos trabalhadores por meio de seus sindicatos, dinâmica de que o movimento de julho de 1962 foi um exemplo. 
